\title{
Winter and Summer Evaluation of Bacteriological Water Quality at Recreational Beaches along Todos Santos Bay, Baja California, Mexico
}

\author{
María Victoria Orozco-Borbón1, Efraín A. Gutiérrez-Galindo1,2, Luis. F. Navarro-0lache1,3, \\ Albino Muñoz-Barbosa',3, Vinicio Macías-Zamora1, Celia Pérez-Capetillo ${ }^{1}$ \\ ${ }^{1}$ Instituto de Investigaciones Oceanológicas, Universidad Autónoma de Baja California, Carretera \\ Transpeninsular Ensenada-Tijuana, Fracc. Playitas, Ensenada, México \\ ${ }^{2}$ Centro de Estudios Tecnológicos del Mar, No. 11 Carretera Ensenada-Tijuana, Ensenada, México \\ ${ }^{3}$ Posgrado en Oceanografía Costera, Facultad de Ciencias Marinas/Instituto de Investigaciones Oceanológicas, \\ Universidad Autónoma de Baja California, Campus Punta Morro, Carretera Tijuana-Ensenada, \\ Ensenada, Mexico \\ Email: mvorozco@uabc.edu.mx
}

Received 30 September 2014; revised 10 November 2014; accepted 24 November 2014

Copyright (C) 2014 by authors and Scientific Research Publishing Inc.

This work is licensed under the Creative Commons Attribution International License (CC BY).

http://creativecommons.org/licenses/by/4.0/

(c) (i) Open Access

\begin{abstract}
Water bacteriological qualities of 22 recreational beaches in Ensenada Bay, Baja California, Mexico were analyzed during the summer and winter of 2008 . Total and fecal coliforms as well as enterococci bacteria were used as pollution indicators. Results showed that bacteria concentrations were higher in winter than summer, associated with Southern California rainy season. Bacteria loads in winter exceeded both the daily and monthly standards showing a clear effect of storm water runoff in the quality of Todos Santos Bay recreational beaches. Statistical analysis showed significant differences between bacteria concentration during summer and winter. The general behavior of the indicators based on daily and monthly standards from high to low was enterococci $>$ FC $>$ TC $>$ total/fecal ratio. Water discharged from 3 sewage treatment plants were responsible for the pollution observed at stations, when the uptake capacity of plants exceeded the storage. During summer pollution was due to non-programmed discharges from sewage treatment plants.
\end{abstract}

\section{Keywords}

Water Quality, Enterococci, Todos Santos Bay

How to cite this paper: Orozco-Borbón, M.V., Gutiérrez-Galindo, E.A., Navarro-Olache, L.F., Muñoz-Barbosa, A., MacíasZamora, V. and Pérez-Capetillo, C. (2014) Winter and Summer Evaluation of Bacteriological Water Quality at Recreational Beaches along Todos Santos Bay, Baja California, Mexico. Advances in Microbiology, 4, 1132-1139.

http://dx.doi.org/10.4236/aim.2014.415123 


\section{Introduction}

Recreational beaches are considered an important economic resource worldwide. They must, however, comply with microbiological standards established for recreational waters in order to protect the health of beach users. Some of the most common illnesses associated with swimming in contaminated waters are typhoid, gastroenteritis, hepatitis, dermatitis, otitis, and conjunctivitis [1]-[3].

The city of Ensenada, located in Baja California (Mexico), has a population of 450,000 and lies along Todos Santos Bay, whose beaches are frequented by locals and visitors for recreational purposes (e.g., swimming, surfing, and diving). To protect bathers from illnesses, researchers at the University of Baja California have undertaken continuous water quality studies following microbiological guidelines and standards to provide reliable and opportune information for public health authorities and beach users. Such studies are based on water quality criteria. According to [4], "A water quality criterion is defined as a quantifiable exposure-effect relationship based on scientific evidence between the level of some indicator of the quality of the water concerned and the potential human health risks associated with the recreational use of that water". The most common microbiological indicators are total coliforms, fecal coliforms, Escherichia coli and enterococci.

The microbiological studies of Todos Santos Bay have shown that some of the beaches regularly used by the population, including the main municipal beach, are being influenced by wastewater discharges. Concentrations of coliform bacteria and enterococci exceeding the limits established for primary contact recreation waters have been detected at these beaches [5] [6]. Simental-Oceguera and Martínez-Hurtaza [7] found bacterial indicators of pollution and identified 20 Salmonella serotypes in residual waters $(16.2 \%)$ and seawater $(2.3 \%)$. The evidence clearly suggests that extensive long-term monitoring of the bay is necessary. This study thus aimed to determine the bacteriological quality of the seawater in Todos Santos Bay, considering the main recreational beaches from the northernmost to the southernmost part of the bay.

\section{Materials and Methods}

Seawater samples were collected from 22 stations at beaches located between El Sauzal and Punta Banda in Todos Santos Bay, Baja California, Mexico (Figure 1). Samples were obtained weekly during five consecutive weeks in summer and winter 2008 using stratified random sampling, and their location was determined by GPS. Samples were collected in sterile bottles, placed in an ice chest and transported to the laboratory for immediate

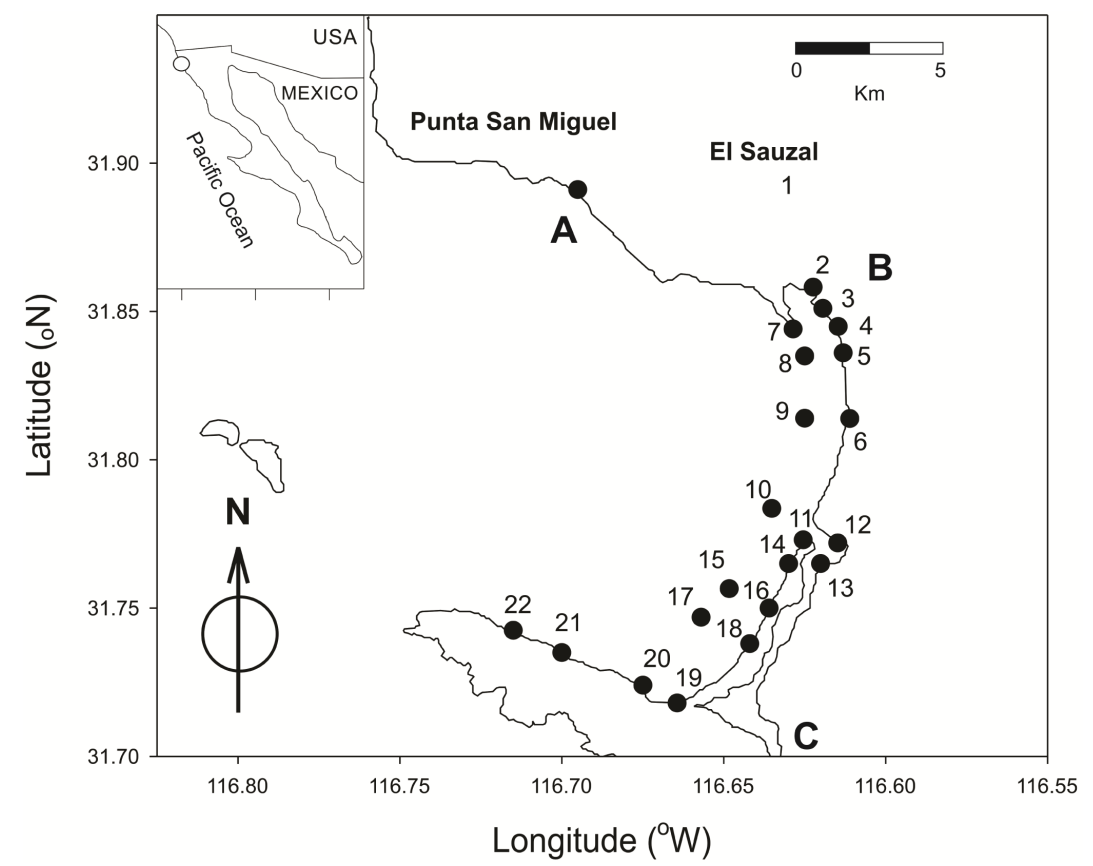

Figure 1. Location of Todos Santos Bay area, Baja California México. Black dots show the position of the 22 water quality stations. A and B indicate the location of city water treatment plants discharges at the beach; C indicates the location of agricultural discharges from San Carlos creek at Punta Banda Estero. 
analysis in duplicate. Total coliforms (TC) and fecal coliforms (FC) were analyzed by the five-tube most probable number method [8]. Analysis consisted of presumptive and confirmed tests; lactose broth was used as presumptive medium at $35^{\circ} \mathrm{C}$ for $24-48$ hours. For confirmed test, $2 \%$ brilliant green bile medium was used for TC at $35^{\circ} \mathrm{C}$ for 48 hours, and $\mathrm{EC}$ medium for $\mathrm{FC}$ at $44.5^{\circ} \mathrm{C}$ in water bath for 24 hours. Enterococci were enumerated by membrane filtration on $\mathrm{mE} 1$ agar according to method 1600 [9], before being incubated at $41^{\circ} \mathrm{C}$ for 24 hours. The Total/fecal ratio was the fourth bacterial indicator [6]. Data were compared (Table 1) to the Single Sample Standard (SSS) and the 30-Day Sample Standard (30-DSS) established in the California Ocean Plan [10]. Salinity was determined with a Beckman Inductive Salinometer, RS10 model, temperature $\left({ }^{\circ} \mathrm{C}\right)$ was obtained with a Fisher Scientific digital calibrated thermometer, and $\mathrm{pH}$ was measured with a Fisher Scientific Potentiometer, Accumet model.

\section{Results}

The percentage of samples that exceeded the Single Sample Standard (SSS) is shown in Table 2. The levels of enterococci in the samples ( $21.81 \%$ in winter and $10 \%$ in summer) were higher than those of TC and FC, though the latter two were also higher in winter than in summer. The Mann-Whitney statistical analysis $(\mathrm{p}<0.05)$ of indicator bacteria in both seasons showed significant differences between the summer and winter concentrations. The general behavior was enterococci $>\mathrm{FC}>$ total/fecal ratio $>\mathrm{TC}$. In summer, $8.18 \%$ of the samples exceeded at least one SSS and $84.54 \%$ did not exceed any, whereas in winter, $7.27 \%$ of the samples exceeded at least one SSS and $76.36 \%$ did not exceed any (Table 3 ).

The percentage of samples that exceeded the established 30-DSS is given in Table 4. Similarly to SSS, enterococci exceeded the 30-DSS in a higher percentage, $50 \%$ in winter and $13.64 \%$ in summer (Table 4). Also during winter, $59.80 \%$ of the samples exceeded at least one 30-DSS, compared with $18.20 \%$ in summer (Table 5).

\section{Table 1. Indicator thresholds used in the shoreline microbiology study. GM = geometric mean over 30-day period.}

\begin{tabular}{ccc}
\hline Indicator & Single Sample Standard (SSS) (cfu or MPN per 100 $\left.\mathrm{mL}^{-1}\right)$ & $\begin{array}{c}\text { 30-Day Sample Standard (30-DSS) } \\
\left(\mathrm{cfu} \text { or MPN per } 100 \mathrm{~mL}^{-1}\right)\end{array}$ \\
\hline Total Coliforms & 10,000 & $20 \%$ of samples $>1000$ \\
Fecal Coliforms & 400 & $200(\mathrm{GM})$ \\
Enterococci & 104 & $35(\mathrm{GM})$ \\
Total/Fecal Ratio & $\begin{array}{c}\text { When TC }>1000 \text { and TC/FC } \leq 10 \text { also, } \\
\text { when TC }>1000 \text { and TC/FC } \leq 5\end{array}$ \\
\hline
\end{tabular}

Table 2. Percent of Single Sample Standard (SSS) exceeder in shoreline.

\begin{tabular}{rcccc}
\hline Indicator & Total Coliforms & Fecal Coliforms & Enterococci & TC $>1000$ and TC/FC $\leq 10$ \\
\hline Summer & 0 & 9 & 10 & 9 \\
Winter & 3.63 & 17.27 & 21.81 & 14.54 \\
\hline
\end{tabular}

Table 3. Percent of samples that exceeded Single Sample Standard (SSS) for single or multiple indicators.

\begin{tabular}{cccccc}
\hline Indicator & All 4 & Any 3 & Any 2 & Any 1 & None \\
\hline Summer & 0 & 3.64 & 3.64 & 8.18 & 84.54 \\
Winter & 1.82 & 9.10 & 5.45 & 7.27 & 76.36 \\
\hline
\end{tabular}

Table 4. Percent of 30-Day Sample Standard (30-DSS) exceeders in shoreline.

\begin{tabular}{cccc}
\hline Indicator & Total Coliforms & Fecal Coliforms & Enterococci \\
\hline Summer & 9.09 & 9.09 & 13.64 \\
Winter & 18.18 & 9.09 & 50 \\
\hline
\end{tabular}


Table 5. Percent of samples that exceeded 30-Day Sample Standard (30-DSS) for single or multiple indicators.

\begin{tabular}{ccccc}
\hline Indicator & All 3 & All 2 & All 1 & None \\
\hline Summer & 4.55 & 4.55 & 9.10 & 81.80 \\
Winter & 18.88 & 9.10 & 31.82 & 40.20 \\
\hline
\end{tabular}

Figure 2 shows the mean concentrations of TC, FC, and enterococci. In winter, the highest mean concentrations occurred at station 2 (Arroyo Ensenada): 55,966 TC $100 \mathrm{~mL}^{-1}, 19,008 \mathrm{FC} 100 \mathrm{~mL}^{-1}$, and 2863 enterococci CFU $100 \mathrm{~mL}^{-1}$. All three indicators exceeded the 30-DSS because TC exceeded $1000 \mathrm{MPN}$ in $100 \mathrm{~mL}^{-1}$ by $80 \%$. The geometric mean for FC was 1324, much higher than the threshold value of $200 \mathrm{FC} 100 \mathrm{~mL}^{-1}$, and the geometric mean for enterococci was 1842, much higher than the 30-DSS value of 35 enterococci $100 \mathrm{~mL}^{-1}$. In summer, the highest mean concentrations of TC (1252 TC $\left.100 \mathrm{~mL}^{-1}\right)$ and enterococci $\left(389 \mathrm{CFU} 100 \mathrm{~mL}^{-1}\right)$ occurred at station 3 (Playa Municipal), the TC exceeded their established 30-DSS by 60\% and enterococci geometric mean was higher than 35. The maximum FC value (676 FC $\left.100 \mathrm{~mL}^{-1}\right)$ was recorded at station 1 (Playa California), and the geometric mean was 395, much higher than the limit of $200 \mathrm{FC} 100 \mathrm{~mL}^{-1}$. In general, the stations located in the southern part of Todos Santos Bay (stations 10 to 22) had the lowest concentrations of indicator bacteria in both seasons even though there are bivalve cultivation sites in this area.

There was a strong correlation between TC and FC in winter $(\mathrm{r}=0.976, \mathrm{p}<0.05)$ and summer $(\mathrm{r}=0.823 \mathrm{p}<$ $0.05)$. Enterococci showed a strong correlation with TC $(r=0.898 p<0.05)$ and $\mathrm{FC}(\mathrm{r}=0.886, \mathrm{p}<0.05)$ in winter, however enterococci shown a very low correlation between TC and FC during summer $(\mathrm{r}=0.491$ and $\mathrm{r}$ $=0.447, \mathrm{p}<0.05)$ respectively.

Salinity values of approximately 33 were recorded at most stations during both sampling periods (Figure 3(a)). Stations 3 (Playa Municipal), 6 (Ciprés), 2 (Arroyo Ensenada), and 1 (Playa California) had the lowest salinity values $(22.59,26.91,30.27$, and 31.77 , respectively).

Seawater temperature ranged from $13.50^{\circ} \mathrm{C}$ to $15.86^{\circ} \mathrm{C}$ in winter and from 16.2 to $26.3^{\circ} \mathrm{C}$ in summer (Figure 3(b)). In winter, the highest temperatures were recorded at stations 3 (Playa Municipal) and 6 (Ciprés), and in summer, at stations 13 (inner part of Punta Banda Estuary, $26.3^{\circ} \mathrm{C}$ ) and 14 (off Punta Banda Estuary, 25.7 ${ }^{\circ} \mathrm{C}$ ). In general, the summer values for stations 12,13 , and 14 were $10^{\circ} \mathrm{C}$ higher than the winter values, but at the other stations the difference was not as marked.

In summer, $\mathrm{pH}$ ranged from 7.75 to 8.37 and in winter, from 7.99 to 8.17 (Figure 3(c)). The lowest pH values in summer were recorded at station 2 (Arroyo Ensenada) and in winter at station 6 (Ciprés).

\section{Discussion}

The higher bacterial concentrations detected in winter in Todos Santos Bay can be attributed to rainfall, which fluctuated between 4.9 and $22.9 \mathrm{~mm}$. The effect of runoff on beach quality was evident since the percentage of samples that exceeded at least one of the three 30-DSS. Winter was three times higher than summer, similar to that reported for the Southern California Bight [11]. The city of Ensenada generates a wide variety of pollutants, (e.g., heavy metals, microorganisms, animal waste, organic matter) that are transported to the coastal zone in winter by runoff [12]. Moreover, during storms, the treatment plants are unable to process all the sewage, then water is discharged untreated at stations 1 (Hotel California) and 3 (Arroyo El Gallo) (Figure 1).

Studies conducted in the Southern California Bight [11] [13]-[16] and in northwestern Baja California [17] [18] have found that runoff can influence the microbiological quality of seawater. In our study, the highest concentrations of indicator bacteria were found at Stations 1 (Playa California), 2 (Arroyo Ensenada), and 3 (Playa Municipal), clearly influenced by stormwater runoff; however, note that stations 1 and 3 are located, close to the discharges from the El Sauzal and Naranjo-El Gallo treatment plants (inland, Figure 1) in which other studies did not find differences between winter and summer conditions due to scant rainfall [6]. The winter salinity measurements indicate freshwater input at Stations 3 (22.59), 6 (26.91), 2 (30.27), and 1 (31.77) (Figure 3(a)), and there were high negative correlation coefficients $(0.924,0.932$ and 0.897$)$ between CT, CF and Enterococci respectively and salinity, except at Station 3, which showed a negative correlation only with FC. The same behavior was found in $\mathrm{pH}$ values, showing high and negative correlations with CT and CF (0.919 and 0.942) respectively. None significantly correlation was found with enterococci.

Stations 1, 2, and 3 had the highest concentrations of indicator bacteria in winter because they are located 

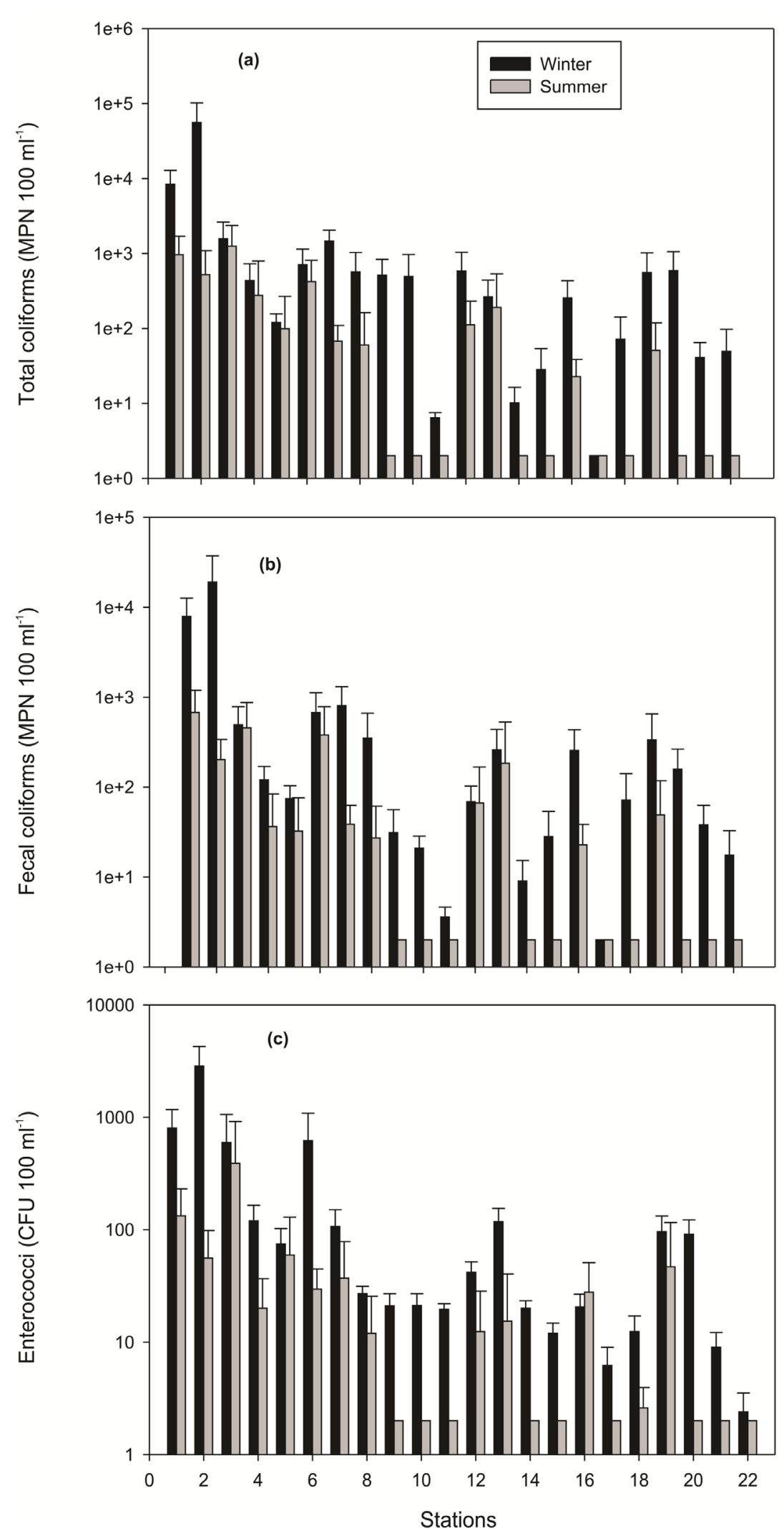

Figure 2. (a) total coliforms; (b) Fecal coliforms; (c) Enterococci bacterial concentrations (mean \pm standard error) for summer and winter. 

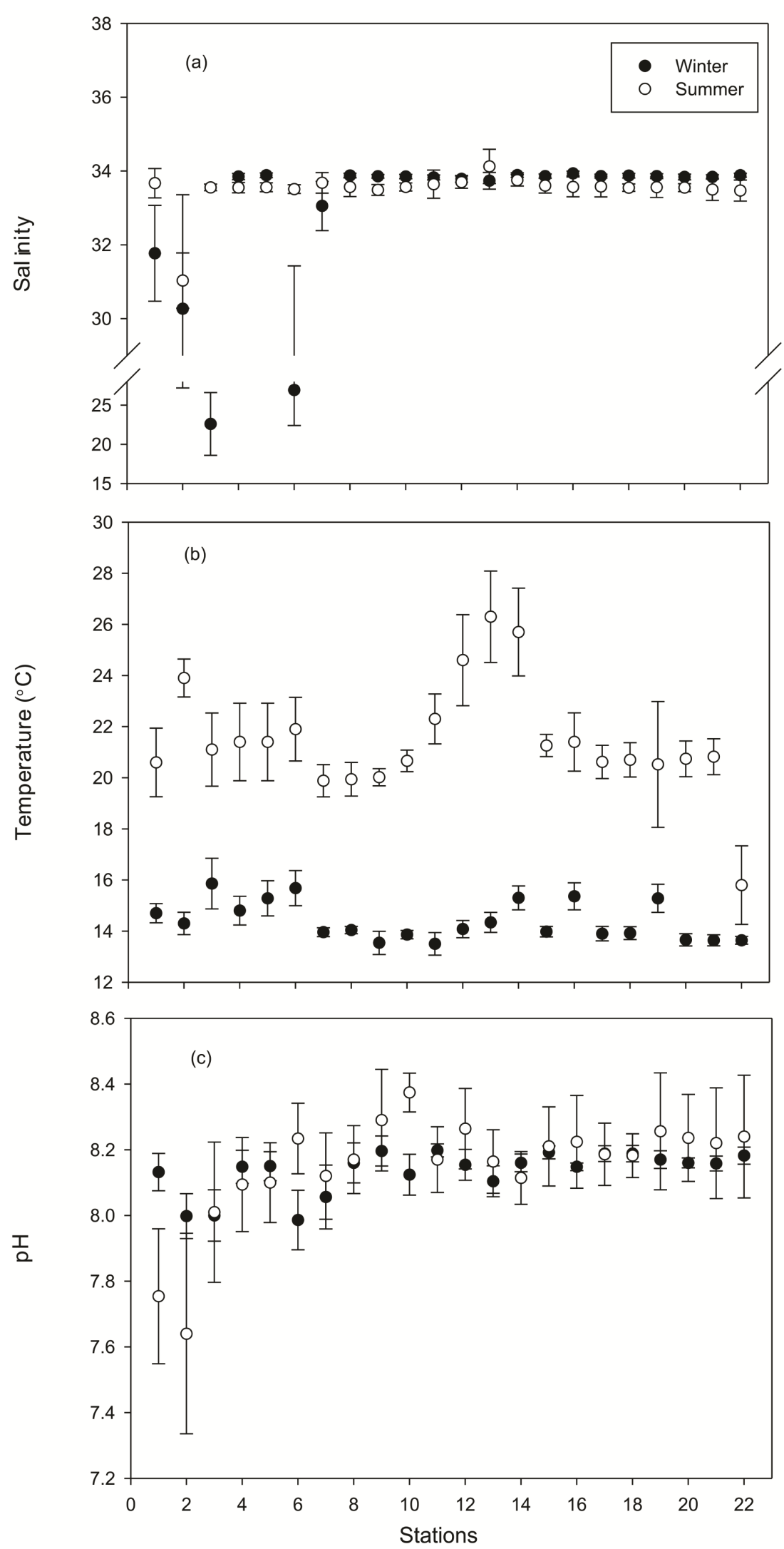

Figure 3. (a) Salinity; (b)Temperature; (c) pH values (mean \pm standard error) for summer and winter. 
closer to stormwater discharges. Station 1 (Playa California) receives the discharge from Arroyo El Sauzal (stream) with an approximately basin of $73.13 \mathrm{~km}^{2}$ and a mean annual runoff volume of 1.076 million $\mathrm{m}^{3}$ [12]. Station 2 (Arroyo Ensenada) receives the waters from two tributaries, Doña Petra and Aguajito stream, that are part of Ensenada Basin. This covers an approximately area of $265.69 \mathrm{~km}^{2}$, with a mean annual runoff volume of 5.195 million $\mathrm{m}^{3}$ [12]. Station 3 (Playa Municipal) is located close to Arroyo El Gallo and receives stormwater from El Gallo Basin, which has an area of $153.07 \mathrm{~km}^{2}$ and a mean annual runoff volume of 2.867 million $\mathrm{m}^{3}$ [12], as well as wastewater discharges from the El Gallo and Naranjo treatment plants.

The pollution detected in winter at station 6 (Ciprés) can be attributed to the effluent discharged from the El Naranjo sewage treatment plant. Under normal conditions, wastewater that has undergone secondary treatment and has a biochemical oxygen demand of $92 \%$ is sent to the El Gallo treatment plant to be discharged through Arroyo El Gallo. During the rainy season, however, stormwater is captured in the city's drainage system and arrives at the treatment plant together with the residual domestic waters. When the plant's capacity is exceeded, untreated water could be bypass to the coastal zone (station 6) via an emergency connection. From time to time untreated water has been diverted to the coastal zone due to improper maintenance or operating problems at the treatment plant, causing beach closures due to high levels of enterococci [19] [20].

In winter, at Stations 12 (Estero Beach) and 13, levels of enterococci exceeded the limits established for recreational waters, probably due to pollutants transported by Arroyo San Carlos, although a decrease in salinity was not detected. Arroyo San Carlos is a single channel stream that crosses the San Carlos Valley and discharges a non-significant volume in Punta Banda Estuary [12]. The levels of enterococci also exceeded the established limits at Stations 19 and 20 (La Joya) due to runoff. Simental-Oceguera and Martínez-Urtaza [7] isolated and identified Salmonella in $3.6 \%$ of the samples taken at Station 20 during the rainy season.

In summer, the bacterial contamination found at Station 1 (Playa California) is due to nonpoint source pollution from the fishing industry and from houses not connected to the sewerage system, as well as the sewage from El Sauzal treatment plant. The contamination at Station 2 is due to the Arroyo Ensenada discharges, and at Station 3 it is due to the joint discharge of residual waters from the El Gallo and Naranjo treatment plants. All the other stations presented good bacteriological quality.

In both summer and winter, enterococci exceeded the SSS and 30-DSS in a higher percentage of stations than coliform bacteria. This is consistent with what has been found inside Ensenada Bay [6] and the California coastal zone [11] [21]. Since enterococci can survive longer in marine environments than coliform bacteria, they are more resistant in seawater [22]; hence, enterococci are better indicators of shoreline water quality, as has been demonstrated [21]. Another reason to use enterococci is that the limits established to determine the seawater bacteriological quality for recreational uses are based on narrower values.

Fecal coliform bacteria are a subgroup of the total coliform group, and this explains the high correlations found between them in summer and winter. Enterococci showed high positive correlations with coliform bacteria in winter because freshwater input due to rainfall decreased salinity at the stations closest to the streams and the survival of coliform bacteria increased. In contrast, in summer, streams did not discharge freshwater and mean salinity was 33 , reducing the survival of coliform bacteria.

In this work winter and summer temperature showed significant differences. Although sea water temperature increases during summer are expected to have a positive influence on survival and amount of indicator bacteria, our data shown that bacteria concentration in the area were fewer than winter values. Higher concentration during winter may indicate that concentration of bacteria is regulated by the raining season discharged in the Bay.

\section{Conclusion}

The levels of indicator bacteria were on average higher in winter (rainy season) than in summer, indicating a clear effect of stormwater runoff on the water quality of recreational beaches at Todos Santos Bay. The treatment plant effluents discharged at Stations 1 and 3 were also responsible for the contamination observed in winter when the treatment and storage capacity of the plants was exceeded. The bacterial contamination found in summer was due to nonpoint source pollution and discharges from the Ensenada treatment plants.

\section{References}

[1] Cabelli, V.J., Dufour, A.P., McCabe, L.J. and Levin, M.A. (1982) Swimming-Associated Gastroenteritis and Water Quality. American Journal of Epidemiology, 115, 606-616.

[2] Pruss, A. (1998) Review of Epidemiological Studies on Health Effects from Exposure to Recreational Water. Interna- 
tional Journal of Epidemiology, 27, 1-9. http://dx.doi.org/10.1093/ije/27.1.1

[3] Haile, R.W., Witte, J.S., Gold, M., Cressey, R., McGee, C., Millikan, R.C., Glasser, A., Harawa, N., Ervin, C., Harmon, P., Harper, J., Dermand, J., Alamillo, J., Barrett, K., Nides, M. and Wang G. (1999) The Health Effects of Swimming in Ocean Water Contaminated by Storm Drain Runoff. Epidemiology, 10, 355-363. http://dx.doi.org/10.1097/00001648-199907000-00004

[4] Salas, H.J. (2000) Historia y aplicación de normas microbiológicas de calidad de agua en el medio marino. Centro Panamericano de Ingeniería Sanitaria y Ciencias del Ambiente (CEPIS). OPS-OMS. Hojas de Divulgación Técnica, 29, $1-11$.

[5] Seañez-Reyes, R. (2001) Aislamiento de bacteriófagos y su aplicación en la contaminación de la Bahía de Todos Santos. B.C. Tesis de Maestría, Universidad Autónoma de Baja California, Ensenada.

[6] Orozco-Borbón, M.V., Rico-Mora, R., Weisberg, S.B., Noble, R.T., Dorsey, J.H., Leecaster, M.K. and McGee, C.D. (2006) Bacteriological Water Quality along the Tijuana-Ensenada, Baja California, Mexico Shoreline. Marine Pollution Bulletin, 52, 1190-1196. http://dx.doi.org/10.1016/j.marpolbul.2006.02.005

[7] Simental-Oceguera, L. and Martínez-Hurtaza, J. (2008) Climate Patterns Governing the Presence and Permanence of Salmonellae in Coastal Areas of Bahia de Todos Santos, Mexico. Applied and Environmental Microbiology, 74, 59185924. http://dx.doi.org/10.1128/AEM.01139-08

[8] APHA (1995) Standard Methods for the Examination of Water and Wastewater. 19th Edition, American Public Health Association, New York.

[9] EPA (2002) Method 1600: Enterococci in Water by Membrane Filtration Using Membrane-Enterococcus Indoxyl- $\beta$-D-Glucoside Agar (mE1). United States Environmental Protection Agency, Office of Water, Washington DC, 14 p.

[10] California Ocean Plan (1990) Water Quality Control Plan for Ocean Waters of California. State Water Resources Control Board, Sacramento.

[11] Noble, R.T., Weisberg, S.B., Leecaster, M.K., McGee, C.D., Dorsey, J.H., Vainik, P. and Orozco-Borbón, V. (2003) Storm Effects on Regional Beach Water Quality along the Southern California Shoreline. Journal of Water and Health, 1, 23-31.

[12] Programa Integral del Agua de Ensenada (PIAE) (2008) Instituto Municipal deInvestigación y Planeación de Ensenada, B.C. (IMIP), Gobierno del Estado de Baja California. Ensenada, B.C., 22-72.

[13] Jiang, S., Noble, R. and Chu, W. (2001) Human Adenoviruses and Coliphages in Urban Runoff-Impacted Coastal Waters of Southern California. Applied and Environmental Microbiology, 67, 179-184. http://dx.doi.org/10.1128/AEM.67.1.179-184.2001

[14] Shiff, K.C., Morton, J. and Weisberg, S.B. (2003) Retrospective Evaluation of Shoreline Water Quality along Santa Monica Bay Beaches. Marine Environmental Research, 56, 245-253. http://dx.doi.org/10.1016/S0141-1136(02)00333-1

[15] Reeves, R.L., Grant, S.B., Mrse, R.D., Copil-Oancea, C.M., Sanders, B.F. and Boehm, A.B. (2004) Scaling and Management of Fecal Indicator Bacteria in Runoff from a Coastal Urban Watershed in Southern California. Environmental Science \& Technology, 38, 2637-2648. http://dx.doi.org/10.1021/es034797g

[16] Griffith, J.F., Schiff, K.C., Lyon, G.S. and Fuhrman, J.A. (2010) Microbiological Water Quality at Non-Human Influenced Reference Beaches in Southern California during Wet Weather. Marine Pollution Bulletin, 60, 500-508. http://dx.doi.org/10.1016/j.marpolbul.2009.11.015

[17] Segovia-Zavala, J.A. and Orozco-Borbón, M.V. (1986) Calidad bacteriológica del agua de mar en la zona costera noroccidental de Baja California. Ciencias Marinas, 12, 93-102.

[18] Orozco-Borbón, M.V., Segovia-Zavala, J.A., Delgadillo-Hinojosa, F. and Muñoz-Barbosa, A. (1994) Estudio bacteriológico de agua de mar para el cultivo de moluscos bivalvos en Baja California. Ciencias Marinas, 20, 183-198.

[19] Vargas, E. (2011) Quedó resuelto el problema en planta de El Naranjo. Ensenada.net. http://www.ensenada.net/noticias/nota.php?ld=21892

[20] Pedraza, I. (2012) Aumenta contaminación en playas de Ensenada. Periódico El Universal. http://www.eluniversalcom.mx/notas/837967.html

[21] Noble, R.T., Moore, D.F., Leecaster, M.K., McGee, C.D. and Weisberg, S.B. (2003) Comparison of Total Coliform, Fecal Coliform and Enterococcus Bacterial Indicator Response for Ocean Recreational Water Quality Testing. Water Research, 37, 1637-1643. http://dx.doi.org/10.1016/S0043-1354(02)00496-7

[22] Hartke, A., Lemarinier, S., Pichereau, V. and Auffray, Y. (2002) Survival of Enterococcus faecalis in Seawater Microcosms Is Limited in the Presence of Bacterivorous Zooflagellates. Current Microbiology, 44, 329-335. http://dx.doi.org/10.1007/s00284-001-0018-4 
Scientific Research Publishing (SCIRP) is one of the largest Open Access journal publishers. It is currently publishing more than 200 open access, online, peer-reviewed journals covering a wide range of academic disciplines. SCIRP serves the worldwide academic communities and contributes to the progress and application of science with its publication.

Other selected journals from SCIRP are listed as below. Submit your manuscript to us via either submit@scirp.org or Online Submission Portal.
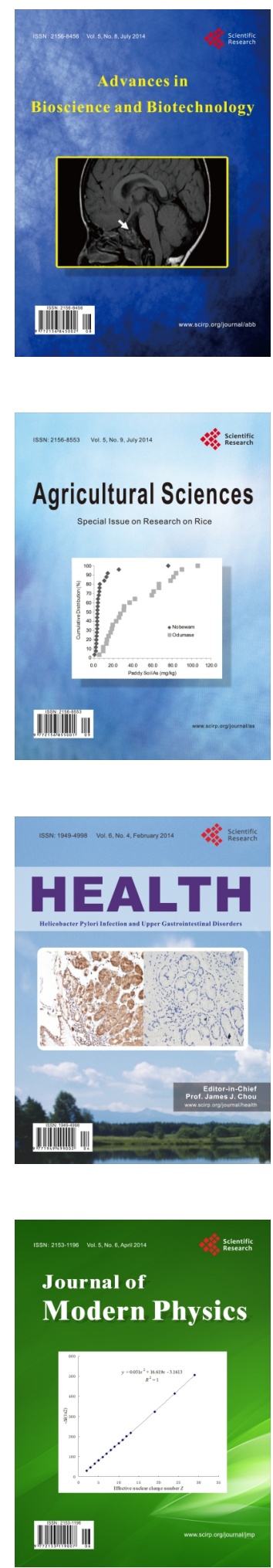
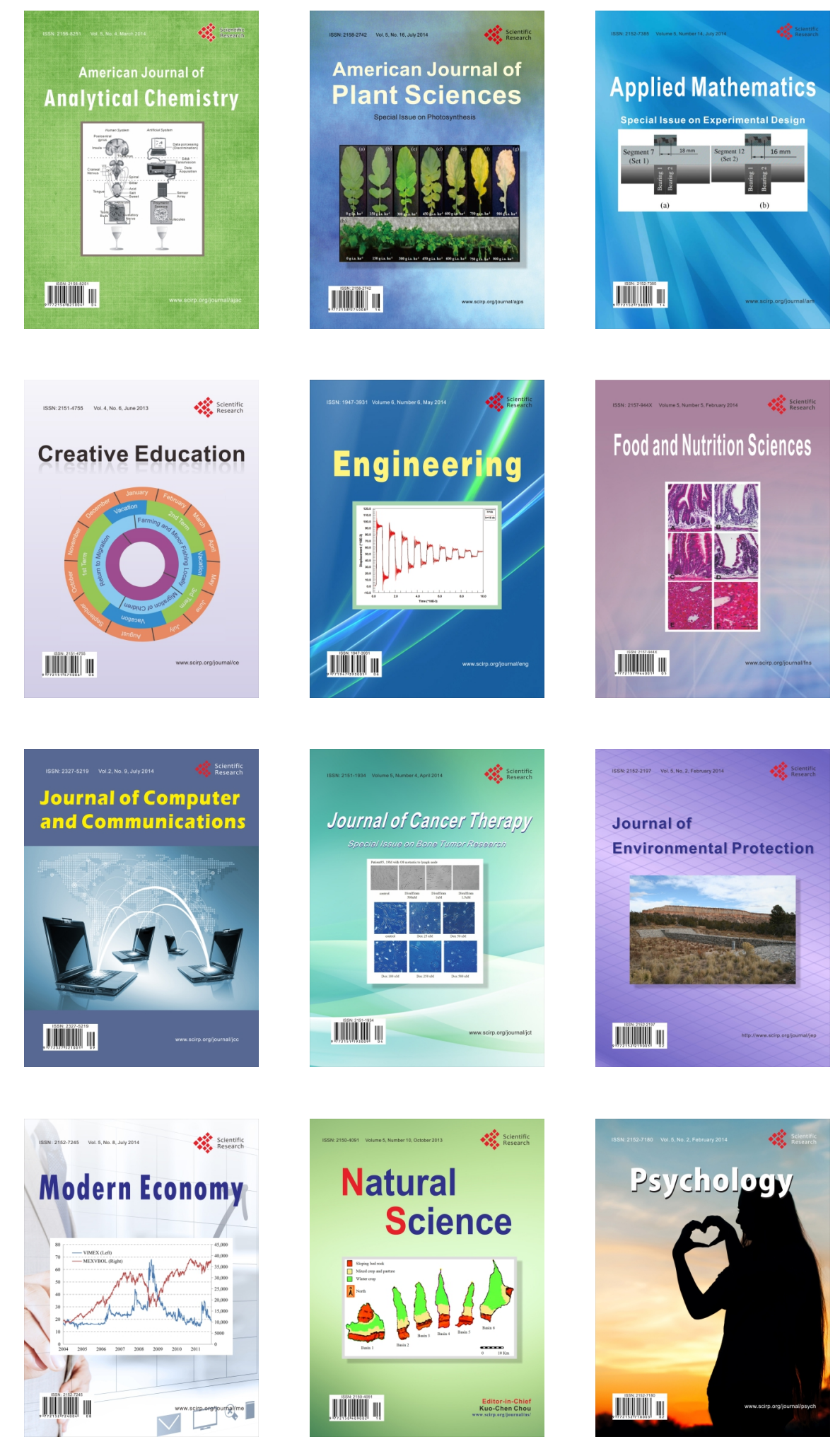